\title{
KEHIDUPAN SOSIAL PENAMBANG EMAS DI KELURAHAN PASAR HILIR KECAMATAN PANYABUNGAN KABUPATEN MANDAILING NATAL
}

\author{
Oleh: \\ Ari Bilkisti*, Helfia Ideal**, Deded Chandra** \\ *Mahasiswa Jurusan Geografi **Dosen Jurusan Geografi FIS Universitas Negeri \\ Padang \\ Email: Helfia.edial@ fis.unp.ac.id dededchandra@gmail.com
}

\begin{abstract}
Abstrak
Penelitian ini bertujuan untuk mendapatkan data, mengolah, menganalisis dan membahas tentang Kehidupan Sosial Masyarakat Penambang Emas Kelurahan Pasar Hilir Kecamatan Panyabungan Kabupaten Mandailing Natal ditinjau dari: 1) hubungan kekerabatan masyarakat penambang emas, 2) cara pandang penambang emas terhadap pergaulan masyarakat, 3) cara pandang penambang emas terhadap budaya gotong royong masyarakat, 4) kehidupan rumah tangga masyarakat penambang emas. Jenis penelitian ini tergolong pada penelitian deskriptif kuantitatif. Populasi penelitian ini adalah seluruh kepala keluarga yang memiliki profesi sebagai penambang emas di Kelurahan Pasar Hilir Kecamatan Panyabungan. Sampel penelitian diambil dengan teknik Proportional Random Sampling yakni pengambilan sampel dari anggota populasi dengan menggunakan acak tanpa memperhatikan strata dalam populasi. Pengumpulan data menggunakan angket terbimbing, Skala pengukuran yang digunakan dalam penelitian ini dengan menggunakan metode Likerts Summated Rating (LSR), dengan menggunakan 5 (lima) kategori jawaban setiap jawaban responden menggunakan interval 1 sampai dengan 5.Berdasarkan hasil penelitian ditemukan bahwa Kehidupan Sosial Masyarakat Penambang Emas Kelurahan Pasar Hilir Kecamatan Panyabungan Kabupaten Mandailing Natal sebagai berikut: 1) Hubungan kekerabatan masyarakat penambang emasdalam kategori baik dengan skor 1890, 2) Cara pandang penambang emas terhadap pergaulan masyarakat dikategorikan cukup baik dengan skor rata-rata 1442, 3) Cara pandang penambang emas terhadap budaya gotong royong masyarakat dikategorikan cukup baik dengan skor rata-rata 1434, 4) Kehidupan rumah tangga masyarakat penambang emas dikategorikan baik dengan skor rata-rata 841.
\end{abstract}

Kata Kunci: kehidupan sosial, penambang emas

\section{PENDAHULUAN}

Manusia merupakan mahkluk yang memiliki keinginan untuk menyatu dengan sesamanya serta dengan alam lingkungan sekitarnya. Dengan menggunakan pikiran, naluri, perasaan, keinginan, dan sebagainya. Manusia memberi reaksi dan melakukan interaksi dengan lingkungannya. Pola interaksi sosial dihasilkan oleh hubungan yang berkesinambungan dalam suatu masyarakat. Masyarakat merupakan suatu kesatuan atau hubungan yang tidak dapat dipisahkan dari kehidupan manusia, karena secara khodratnya manusia merupakan makhluk individu dan makhluk sosial. Manusia yang satu tidak dapat hidup sendiri dan selalu 
berhubungan dan membutuhkan orang lain. Dalam kehidupan bermasyarakat, setiap individu berbeda.Setiap individu mempunyai kehidupan yang berbeda termasuk pekerjaan yang digelutinya. Pekerjaan tersebut sesuai dengan keahlian dan kemampuan yang masingmasing dimilikinya. Mata pencaharian sangat menentukan kelangsungan hidup seseorang. Apalagi dizaman sekarang, dimana semua kebutuhan manusia semakin mahal. Sehingga menyebabkan individu yang mempunyai penghasilan yang rendah akan kesulitan untuk memenuhi kebutuhan hidupnya (Efriwan.2009).

Kecamatan

Panyabungan

merupakan salah satu kecamatan yang memiliki kekayaan alam yang melimpah. Kekayaan mineral yang dimiliki Kecamatan Panyabungan yang paling hangat baru-baru ini yaitu mineral tambang emas. Kelurahan Pasar Hilir yang terdapat di Kecamatan Panyabungan merupakan salah satu kelurahan yang memiliki masyarakat sebagian besar adalah penambang emas. Kegiatan penambangan emas ini mulai dilakukan masyarakat Panyabungan pada tahun 2008 tetapi itu hanya dilakukan oleh beberapa orang saja karena hanya sebagian orang saja yang mengetahui cara bagaimana melakukan pertambangan

tradisional.

Penambangan ini pertama kali dilakukan bukan oleh masyarakat sekitar akan tetapi dilakukan oleh pendatang yang berada diluar kecamatan karena masyarakat Panyabungan belum mengerti mengenai ilmu pertambangan dan belum mengetahui bagaimana cara menentukan titik-titik atau lokasi yang akan dijadikan lahan pertambangan.
Masyarakat mulai tertarik dengan pertambangan setelah mengetahui kabar mengenai keberhasilan pengelolaan tambang yang berada di gunung dan mulai meninggalkan kegiatan pendulangan di sungai.Umumnya lokasi pertambangan ini adalah perkebunan masyarakat sekitar yang mana kebun tersebut telah dikelola oleh masyarakat berpuluh-puluh tahun yang lalu karena penghasilan masyarakat sekitar adalah dari perkebunan.

Penambangan emas yang dilakukan masyarakat Pasar Hilir ini telah banyak memberi perubahan kehidupan sosialnya. Dalam kehidupan sosial, tingkat perekonomian atau kekayaan seseorang sangat berpengaruh terhadap kedudukannya dimata masyarakat. Karena seseorang yang memiliki kekayaan yang banyak akan lebih dihormati dan disegani dalam suatu masyarakat. Perubahan sosial yang terjadi yaitu berupa struktur masyarakat. Dimana setelah maraknya penambangan emas di Kecamatan Panyabungan terdapat struktur sosial baru yang terdiri dari pemilik lahan/tanah, dan pekerja atau buruh. Perubahan sosial yang terjadi terhadap masyarakat. Masalah lain yang terjadi adalah banyaknya masyarakat yang pindah dari daerah penambangan emas ke kota ataupun dari kota ke penambangan emas tersebut. Penambangan emas ini juga menyebabkan masyarakat di Kelurahan Pasar Hilir Kecamatan Panyabungan yang awalnya mempunyai rasa gotong royong dan kekeluargaan yang tinggi, berangsur-angsur menjadi masyarakat yang individual, yaitu masyarakat yang lebih mementingkan kehidupan 
pribadinya sendiri serta mengabaikan kehidupan sosial.

Masalah lainnya yang muncul yaitu banyaknya terjadi konflik dalam rumah tangga masyarakat penambang emas di Kelurahan Pasar Hilir.Dari hal inilah penulis tertarik untuk melakukan penelitian dengan judul "Kehidupan Sosial Penambang Emas di Kelurahan Pasar Hilir Kecamatan Panyabungan Kabupaten Mandailing Natal".

\section{METODE PENELITIAN}

Penelitian ini tergolong jenis penelitian Deskriptif Kuantitatif. Penelitian ini merupakan salah satu bentuk penelitian yang bertujuan untuk menggambarkan atau melukiskan variabel-variabel penelitian. Menurut Sudjana (2007:64), penelitian Deskriptif Kuantitatif digunakan apabila penelitian ini bertujuan untuk mendeskripsikan atau menjelaskan peristiwa dan kejadian yang ada pada masa sekarang, survey studi pengembangan. Informasi atau data yang dipakai antara lain pengamatan, angket dan wawancara. Pengujian ini tidak meneliti hipotesis, melainkan hanya mendeskripsikan informasi apa adanya sesuai dengan variabel-variabel yang diteliti. Jadi penelitianhanya mendeskripsikan informasi tentang Kehidupan Sosial Masyarakat Penambang Emas di Kelurahan Pasar HilirKecamatan Panyabungan dilihat dari hubungan kekerabatan penambang emas dengan masyarakat, cara pandang penambang emas terhadap pergaulan dalam masyarakat, cara pandang penambang emas terhadap gotong royong dalam masyarakat, kehidupan rumah tangga masyarakat penambang emas.

\section{Populasi dan Sampel Penelitian. \\ Populasi Penelitian}

Populasi dalam penelitian ini adalah seluruh kepala keluarga yang memiliki profesi sebagai penambang emas di Kelurahan Pasar Hilir Kecamatan Panyabungan. Adapun jumlah kepala keluarga yang memiliki profesi sebagai penambang emas di Kecamatan Panyabungan Kelurahan Pasar Hilir dapat dilihat pada tabel berikut:

Tabel 1 Jumlah Masyarakat

Penambang Emas Di Kelurahan Pasar Hilir

\begin{tabular}{|l|l|c|}
\hline No & \multicolumn{1}{|c|}{ Nama Dusun } & $\begin{array}{c}\text { Jumlah } \\
\text { KK } \\
\text { (orang) }\end{array}$ \\
\hline 1. & Banjar Dalam & 82 \\
2. & Simpang Opat & 74 \\
3. & Banjar Dalan & 119 \\
4. & Banjar Saba & 128 \\
5. & Banjar Saba Ujung & 122 \\
\hline & \multicolumn{1}{|c|}{ Jumlah } & 525 \\
\hline
\end{tabular}

Sumber : BPS Kabupaten Mandailing Natal 2015

\section{Sampel Penelitian}

Teknik penarikan sampel responden penelitian dilakukan dengan cara dua bentuk yaitu teknik sampling wilayah (area sampling) yang digunakan untuk menentukan wilayah sebagai sampel penelitian dan sampel responden digunakan untuk menentukan besarnya objek penelitian.

a. Sampel Wilayah

Mengingat luasnya wilayah populasi penelitian maka dilakukan penyampelan terhadap wilayah populasi yang ada. Sampel wilayah dilakukan secara purposive sampling yaitu pemilihan sampel dengan cara secara 
sengaja memilih sampel-sampel tertentu (dan mengabaikan sampel-sampel yang lainnya) karena sampel tertentu ini memiliki ciri-ciri khusus yang tidak dimiliki sampel-sampel lainya. (Irawan,1999:183). Berdasarkan observasi yang telah dilakukan sebelum penelitian dimulai, dari 5 (lima) dusun di Kelurahan Pasar Hilir yang dijadikan sampel adalah 3 (tiga)dusun yaitu Banjar Dalan, Banjar Saba dan Banjar Saba Ujung. Ketiga dusun ini dipilih karena memiliki jumlah penambang emas yang lebih banyak dibandingkan dengan wilayah yang lain

Tabel 2 Jumlah Sampel Wilayah

\begin{tabular}{|r|l|c|}
\hline No & Nama Dusun & $\begin{array}{c}\text { Jumlah kk } \\
\text { (orang) }\end{array}$ \\
\hline 1. & Banjar Dalan & 119 \\
2. & Banjar Saba & 128 \\
3. & Banjar Saba & 122 \\
& Ujung & 369 \\
\hline
\end{tabular}

Sumber: Pengolahan Data Primer 2016

b. Sampel Responden

Arikunto (2006: 124) menyatakan sampel adalah sebagian atau wakil populasi kurang dari 100, maka sampel dapat diambil keseluruhan, tetapi apabila telah lebih dari 100 maka dapat diambil sampel sebesar $5-15 \%$ atau 20 - 25\%, karena mengingat jumlah populasi yang banyak dan jawaban responden yang hampir sama, maka peneliti mengambil penarikan sampel sebesar $15 \%$ terhadap kepala keluarga penambang emas yang ada di Kelurahan Pasar Hilir Kecamatan Panyabungan Kabupaten Mandailing Natal. Teknik yang digunakan untuk penarikan sampel adalah Proportional Random Sampling yakni pengambilan sampel dari anggota populasi dengan menggunakan acak tanpa memperhatikan strata dalam populasi di Kelurahan Pasar Hilir Kecamatan Panyabungan Kabupaten Mandailing Natal. Cara pengambilan sampelnya yaitu mengambil data dari kepala keluarga penambang emas di Kelurahan Pasar HilirKecamatan Panyabungan secara acak, dengan cara setiap subjek yang terdaftar sebagai populasi diberi nomor urut mulai dari angka 1 sampai dengan banyaknya subjek. Lalu diambil secara acak, sebanyak jumlah sampel yang akan dijadikan responden Arikunto (2006). Adapun jumlah responden dalam penelitian ini dapat dilihat pada tabel dibawah ini :

Tabel 3

Jumlah Responden Penelitian

\begin{tabular}{|c|l|c|c|c|}
\hline No & $\begin{array}{c}\text { Nama Daerah } \\
\text { (Dusun) }\end{array}$ & $\begin{array}{c}\text { Jumlah } \\
\text { Penambang } \\
\text { (kk) }\end{array}$ & $\begin{array}{c}\text { Proporsi } \\
(\mathbf{\%})\end{array}$ & $\begin{array}{c}\text { Sampel } \\
\text { (orang) }\end{array}$ \\
\hline 1 & BanjarDalan & 119 & $15 \%$ & 18 \\
2 & Banjar Saba & 128 & $15 \%$ & 20 \\
3 & Banjar Saba Ujung & 122 & $15 \%$ & 18 \\
\hline \multicolumn{2}{|c|}{ Jumlah } & 369 & $15 \%$ & 56 \\
\hline
\end{tabular}

Sumber : Pengolahan Data Primer 2016

\section{Variabel dan Data}

Variabel dalam penelitian ini ada 4 variabel yaitu : kekerabatan antar masyarakat, cara pandang masyarakat terhadap pergaulan, gotong royong dan kehidupan rumah tangga masyarakat 
penambang emas di Kelurahan Pasar Hilir Kecamatan Panyabungan Kabupaten Mandailing Natal. Pengukuran dilakukan dengan menggunakan skala likert mengasumsikan jawaban responden menjadi 4 pilihan mulai dari sangat negatif sampai dengan sangat positif (Widoyoko, 2014: 104).

\section{Variabel}

a. Hubungan kekerabatan penambang emas

Kekerabatan yang dimaksud disini adalah hubungan sesama keluarga, sanak famili, teman sejawat maupun teman kerja berdasarkan adanya aturan yang dibuat bersama secara turun temurun maupun berkala.Adapun indikatornya adalah: 1) Keluarga, 2) Tetangga. Pengukuran dilakukan dengan skala likert.

b. Cara pandang penambang emas terhadap pergaulan

Pergaulan yang dimaksud disini adalah jalinan hubungan sosial antara seseorang dengan orang lain yang berlangsung dalam jangka relatif lama sehingga terjadi saling mempengaruhi satu dengan lainnya oleh masyarakat penambang emas di Kelurahan Pasar Hilir Kecamatan Panyabungan adapun indikatornya adalah 1) egoisme 2) solidaritas. Pengukuran dilakukan dengan skala likert.

c. Cara pandang penambang emas terhadap gotong royong

Pengertian gotong royong dalam penelitian ini adalah suatu pekerjaan yang dilakukan bersama-sama baik untuk kepentingan perorangan maupun untuk kepentingan bersama. Untuk mengukurnya digunakan indikator: 1) Tenaga 2) Uang, alat atau konsumsi. 3) fikiran, gagasan atau ide. Pengukuran dilakukan dengan skala likert.
d. Kehidupan rumah tangga penambang emas

Kehidupan rumah tangga dalam penelitian ini yaitu kehidupan yang dialami rumah tangga masyarakat penambang emas. Untuk mengukurnya digunakan indikator: 1) Perkawinan. 2) Perceraian. 3) Keharmonisan. Pengukuran dilakukan dengan skala likert.

\section{Data}

a. Jenis Data

Sesuai dengan tujuan yang hendak dicapai, maka data yang akan dikumpulkan dalam penelitian ini berupa data primer dan data sekunder. Data primer yang dikumpulkan adalah berupa data kehidupan sosial masyarakat penambang emas di Kelurahan Pasar HilirKecamatan Panyabungan yang dilihat dari kekerabatan, cara pandang masyarakat terhadap pergaulan, budaya gotong royong, dan kehidupan rumah tangga. Data primer dikumpulkan melalui wawancara dengan menggunakan angket atau kuisioner yang telah disiapkan. Sedangkan data sekunder didapatkan melalui wawancara, observasi dan pencatatan sesuai yang dibutuhkan dalam penelitian ini.

b. Teknik Pengumpulan Data

Data primer didapatkan melalui wawancara dan dengan menggunakan daftar pertanyaan, kuisioner yang telah dipersiapkan, sedangkan data sekunder diperoleh dari data observasi dan pencatatan, untuk lebih jelasnya dapat dilihat pada tabel 4 berikut ini: 
Tabel 4

Jenis Data, Sumber Data,Teknik dan Alat Pengumpulan Data

\begin{tabular}{|c|c|c|c|c|}
\hline $\begin{array}{l}\mathrm{N} \\
\mathrm{o} .\end{array}$ & Jenis Data & $\begin{array}{c}\text { Sumber } \\
\text { Data }\end{array}$ & $\begin{array}{c}\text { Teknik } \\
\text { Pengumpulan } \\
\text { Data }\end{array}$ & $\begin{array}{c}\text { Alat } \\
\text { Pengumpul } \\
\text { Data }\end{array}$ \\
\hline 1 & $\begin{array}{l}\text { Data sekunder } \\
\text { a. Kondisi Fisik } \\
\text { b. kehidupan Sosial }\end{array}$ & $\begin{array}{l}\text { i. Kantor } \\
\text { Camat }\end{array}$ & $\begin{array}{l}\text { Observasi, } \\
\text { Pencatatan }\end{array}$ & $\begin{array}{l}\text { Daftar } \\
\text { Registrasi }\end{array}$ \\
\hline 2 & $\begin{array}{l}\text { Data Primer } \\
\text { 1. Hubungan kekerabatan penambang emas } \\
\text { 2. Cara pandang penambang emas terhadap } \\
\text { pergaulan masyarakat } \\
\text { 3. Cara pandang penambang emas terhadap } \\
\text { gotong royong masyarakat } \\
\text { 4. Kehidupan rumah tangga penambang } \\
\text { emas }\end{array}$ & $\begin{array}{l}\text { i.Respond } \\
\text { en }\end{array}$ & Angket & $\begin{array}{l}\text { Angket } \\
\text { Angket } \\
\text { Angket }\end{array}$ \\
\hline
\end{tabular}

Sumber: Pengolahan Data Primer 2016

\section{Instrumen Penelitian}

Sesuai dengan jenis data dalam penelitian ini maka instrumen yang digunakan adalah dengan menggunakan daftar pertanyaan atau kuisioner. Sedangkan data yang tidak mungkin dikumpulkan dengan kuisioner dilakukan dengan observasi dan pencatatan langsung pada masyarakat penambang emas di Kelurahan Pasar Hilir Kecamatan Panyabungan Kabupaten Mandailing Natal.

Tabel 5

Kisi-kisi Instrumen

\begin{tabular}{|c|c|c|c|}
\hline No & Variabel & Indikator & Item \\
\hline 1 & $\begin{array}{l}\text { Hubungan } \\
\text { kekerabatan } \\
\text { penambang emas }\end{array}$ & $\begin{array}{ll}\text { a. } & \text { Keluarga } \\
\text { b. } & \text { Tetangga } \\
& \text { /masyaraka } \\
& \mathrm{t}\end{array}$ & $1-12$ \\
\hline 2 & $\begin{array}{l}\text { Cara pandang } \\
\text { penambang emas } \\
\text { terhadap } \\
\text { pergaulan }\end{array}$ & $\begin{array}{ll}\text { a. Solidaritas } \\
\text { b. Egois }\end{array}$ & $13-21$ \\
\hline 3 & $\begin{array}{l}\text { Cara pandang } \\
\text { penambang emas } \\
\text { terhadap gotong } \\
\text { Royong }\end{array}$ & $\begin{array}{l}\text { a. Tenaga } \\
\text { b. Uang/alat/k } \\
\text { onsumsi } \\
\text { c. Fikiran/ide }\end{array}$ & $22-33$ \\
\hline 4 & $\begin{array}{l}\text { Kehidupan rumah } \\
\text { tangga } \\
\text { penambang emas }\end{array}$ & $\begin{array}{ll}\text { a. } & \text { Perkawinan } \\
\text { b. } & \text { Perceraian } \\
\text { c. } & \text { Keharmonis } \\
& \text { an }\end{array}$ & $34-40$ \\
\hline
\end{tabular}

Sumber : Pengolahan Data Primer 2016

\section{Teknik Analisis Data}

Sesuai dengan jenis data yang akan dikumpulkan dalam penelitian deskriptif untuk teknik analisa data menggunakan statistik deskriptif, formula yang digunakan yaitu formula persentase dengan rumus sebagai berikut

$$
\frac{f}{n} \times 100 \% \quad \text { (Bungin, }
$$

2011:182)

Keterangan:

$\mathrm{P} \quad$ : Presentase

f : Frekuensi jawaban responden

n : Jumlah responden

\section{Pengukuran Variabel Penelitian}

Skala pengukuran yang digunakan dalam penelitian ini dengan menggunakan metode Likerts Summated Rating (LSR), dengan menggunakan 5 (lima) kategori jawaban setiap jawaban responden menggunakan interval 1 sampai dengan 5. Millies dan Hubberman (dalam Sugiyono; 2008:337)

Interval jawaban akan disesuaikan dengan pertanyaan yang diajukan seperti berikut ini.

1. Tidak baik (score 1)

2. Kurang baik (score 2)

3. Cukup baik (score 3 )

4. Baik (score 4)

5. Sangat baik (score 5) 
Gambaran tanggapan masyarakat penambang emas mengenai variabel penelitian diberikan dalam bentuk analisis deskriptif untuk setiap variabel berdasarkan frekuensi jawaban pengunjung terhadap indikator variabel yang diteliti. Dengan menggunakan skor rata-rata yang diperoleh dari tanggapan pengunjung selanjutnya ditentukan klasifikasi variabel yang diteliti dengan menentukan rentang skor penilaian berdasarkan rumus :

$$
\begin{aligned}
& \mathrm{RS}=(\mathrm{n} \times(\mathrm{m}-1)) / \mathrm{m} \\
& (\text { Sugiyono; 2008:337) } \\
& \text { Keterangan : } \\
& \mathrm{RS}=\text { Rentang Skor } \\
& \mathrm{n} \quad=\text { Jumlah Responden }
\end{aligned}
$$

$\mathrm{m}=$ Skor nilai tertinggi untuk setiap pertanyaan.

Adapun perhitungan rentang skor dapat dilihat sebagai berikut :

$$
\begin{aligned}
\mathrm{RS} & =(\mathrm{n} \times(\mathrm{m}-1)) / \mathrm{m} \\
& =(56 \times(5-1) / 5 \\
& =(56 \times 4) / 5 \\
& =224 / 5=45
\end{aligned}
$$

Rentang skor terendah $=\mathrm{nx}$ skor nilai terendah $=56 \times 1=56$

Rentang skor tertinggi $=\mathrm{n} \times$ skor nilai

\begin{tabular}{|c|c|c|c|}
\hline No & Variabel & Rentang Penilaian & Kategori Penilaian \\
\hline \multirow{5}{*}{1} & \multirow{5}{*}{$\begin{array}{l}\text { Hubungan kekerabatan } \\
\text { masyarakat penambang emas }\end{array}$} & $56-504$ & Tidak Baik \\
\hline & & $505-1005$ & Kurang Baik \\
\hline & & $1006-1510$ & Cukup Baik \\
\hline & & $1511-2015$ & Baik \\
\hline & & $2016-2520$ & Sangat Baik \\
\hline \multirow{5}{*}{2} & \multirow{5}{*}{$\begin{array}{l}\text { Cara pandang penambang } \\
\text { emas terhadap pergaulan } \\
\text { masyarakat }\end{array}$} & $56-448$ & Tidak Baik \\
\hline & & $449-894$ & Kurang Baik \\
\hline & & $895-1343$ & Cukup Baik \\
\hline & & $1344-1791$ & Baik \\
\hline & & $1792-2240$ & Sangat Baik \\
\hline \multirow{5}{*}{3} & \multirow{5}{*}{$\begin{array}{l}\text { Keterlibatan penambang emas } \\
\text { terhadap gotong royong } \\
\text { masyarakat }\end{array}$} & $56-448$ & Tidak Baik \\
\hline & & $449-894$ & Kurang Baik \\
\hline & & $895-1343$ & Cukup Baik \\
\hline & & $1344-1791$ & Baik \\
\hline & & $1792-2240$ & Sangat Baik \\
\hline \multirow{5}{*}{4} & \multirow{5}{*}{$\begin{array}{l}\text { Kehidupan rumah tangga } \\
\text { penambang emas }\end{array}$} & $56-224$ & Tidak Baik \\
\hline & & $325-449$ & Kurang Baik \\
\hline & & $450-674$ & Cukup Baik \\
\hline & & $675-898$ & Baik \\
\hline & & $899-1120$ & Sangat Baik \\
\hline
\end{tabular}
tertinggi $=56 \times 5=280$

Mengikuti skala Likert yang digunakan dalam penelitian ini, maka dapat dibuat rentang pengklasifikasian masing-masing variabel sebagai berikut ini.

Tabel 6

Rentang Pengklasifikasian Variabel Penelitian

Sumber Data : Pengolahan Data Penelitia 
PEMBAHASAN

\begin{tabular}{llr}
\multicolumn{2}{c}{ Kecamatan } & \multicolumn{2}{c}{ Panyabungan } \\
merupakan salah & satu & dari 23 \\
Kecamatan di Kabupaten & Mandailing \\
Natal Provinsi Sumatera Utara
\end{tabular} Kecamatan yang menjadi pusat kota dari Kabupaten Mandailing Natal ini dibentuk berdasarkan Undang-undang Nomor 12 Tahun 1998, secara formal diresmikan oleh Menteri Dalam Negeri pada tanggal 9 Maret 1999.Dalam konstelasi regional, Kecamatan Panyabungan berada di bagian selatan wilayah Propinsi Sumatera Utara yang secara geografis terletak pada $0^{\circ} 10^{\prime}$ $1^{\circ} 50^{\prime}$ Lintang Utara dan $98^{\circ} 10^{\prime}-100^{\circ} 10^{\prime}$ Bujur Timur dengan rentang ketinggian 400-750 meter di atas permukaan laut (Mdpl). Batas-batas wilayah Kecamatan Panyabungan adalah sebagai berikut:

1. Sebelah utara berbatasan dengan Kecamatan Panyabungan Utara

2. Sebelah selatan berbatasan dengan Kecamatan Panyabungan Selatan

3. Sebelah barat berbatasan dengan Kecamatan Panyabungan Barat dan Kecamatan Hutabargot

4. Sebelah timur berbatasan dengan Kecamatan Panyabungan Timur Sebagian besar wilayah Kecamatan Panyabungan terdiri atas dataran. Sebagian Desa/Kelurahan di Kecamatan Panyabungan merupakan pecahan dari Desa/Kelurahan lain. Desa dengan lokasi terjauh dari pusat pemerintahan adalah Desa Aek Banir yang berjarak sekitar $14 \mathrm{~km}$ dari ibukota Kecamatan dan belum dilalui kendaraan umum yang memadai. Luas wilayah Kecamatan Panyabungan sekitar 25.977, 43 Ha yang sebagian terdiri atas dataran, hanya beberapa desa yang memiliki topografi wilayah berupa lereng atau pegunungan. Diantaranya yaitu Desa Sopo Batu dan Desa Siobon.

\section{Topografi}

Secara Geografis, semua

Desa/Kelurahan di Kecamatan Panyabungan merupakan daerah dataran rendsh,hanya beberapa Desa yang memiliki topografi wilayah berupa lereng atau pegunungan. Diantaranya yaitu Desa Sopo Batu dan Desa Siobon. Kecamatan Panyabungan terletak di Ketinggian antara 400-750 meter di atas permukaan laut (Mdpl).

\section{Iklim}

Kecamatan Panyabungan mempunyai suhu udara berkisar antara $23^{\circ} \mathrm{C}-32^{\circ} \mathrm{C}$ dan kelembaban udara antara 80 - $85 \%$. Pada Tahun 2015 curah hujan maksimum terjadi pada bulan Desember yaitu $3.140 \mathrm{~mm}$ dan curah hujan minimum terjadi pada bulan Januari berkisar $584 \mathrm{~mm}$. Rata rata jumlah curah hujan di kabupaten ini adalah $1.654 \mathrm{~mm} /$ tahun. Kecamatan Muarasipongi merupakan kecamatan dengan curah hujan tertinggi yaitu 3.140 $\mathrm{mm} /$ tahun sedangkan curah hujan terendah terjadi di Kecamatan Panyabungan Utara yaitu 584mm/ tahun.

Pembahasan ialah menafsirkan
atau menginterprestasikan hasil
penelitian. Berdasarkan hasil kuesioner
yang telah diolah dapat disajikan
kehidupan sosial masyarakat penambang
emas Kelurahan Pasar Hilir pada tabel
berikut ini.

Pembahasan ialah menafsirkan penelitian. Berdasarkan hasil kuesioner penelitian. Berdasarkan hasil kuesioner yang telah diolah dapat disajikan kehidupan sosial masyarakat penambang emas Kelurahan Pasar Hilir pada tabe berikut ini. 
Tabel 12

Akumulasi Tanggapan Masyarakat Penambang Emas untuk Masing-Masing Variabel

\begin{tabular}{|c|c|c|c|c|c|c|c|c|}
\hline \multirow[b]{2}{*}{ Variabel } & & \multicolumn{7}{|c|}{ Akumulasi Tanggapan Masyarakat Penambang } \\
\hline & & $\begin{array}{c}\text { Sangat } \\
\text { Tidak } \\
\text { Baik }\end{array}$ & $\begin{array}{l}\text { Tidak } \\
\text { Baik }\end{array}$ & $\begin{array}{l}\text { Cukup } \\
\text { Baik }\end{array}$ & Baik & $\begin{array}{c}\text { Sangat } \\
\text { Baik }\end{array}$ & $\begin{array}{l}\text { Rata- } \\
\text { Rata } \\
\text { Skor }\end{array}$ & Kategori \\
\hline \multirow{2}{*}{$\begin{array}{l}\text { Hubungan } \\
\text { kekerabatan } \\
\text { penambang emas } \\
\text { dengan keluarga } \\
\text { dan masyarakat }\end{array}$} & $\mathrm{F}$ & 0 & 17 & 144 & 291 & 52 & 1890 & \multirow[t]{2}{*}{ Baik } \\
\hline & $\%$ & 0 & 5,37 & 28,54 & 56,09 & 10,54 & & \\
\hline \multirow{2}{*}{$\begin{array}{l}\text { Cara pandang } \\
\text { penambang emas } \\
\text { terhadap egoisme } \\
\text { dan solidaritas } \\
\text { terhadap pergaulan }\end{array}$} & $\mathrm{F}$ & 22 & 69 & 141 & 78 & 45 & 1442 & \multirow[t]{2}{*}{$\begin{array}{c}\text { Cukup } \\
\text { Baik }\end{array}$} \\
\hline & $\%$ & 3 & 5,5 & 22,5 & 49,5 & 19,5 & & \\
\hline \multirow{2}{*}{$\begin{array}{l}\text { Keterlibatan } \\
\text { penambang emas } \\
\text { terhadap gotong } \\
\text { royong dalam } \\
\text { masyarakat }\end{array}$} & $\mathrm{F}$ & 15 & 68 & 167 & 131 & 46 & 1434 & \multirow[t]{2}{*}{$\begin{array}{l}\text { Cukup } \\
\text { Baik }\end{array}$} \\
\hline & $\%$ & 4,2 & 9,78 & 23,57 & 38 & 24,45 & & \\
\hline \multirow{2}{*}{$\begin{array}{l}\text { Keharmonisan } \\
\text { rumah tangga }\end{array}$} & $\mathrm{F}$ & 7 & 44 & 26 & 134 & 21 & \multirow[t]{2}{*}{841} & \multirow{2}{*}{ Baik } \\
\hline & $\%$ & 9,48 & 24,81 & 18,97 & 31,38 & 19,70 & & \\
\hline
\end{tabular}

Sumber Data : Hasil Pengolahan Data Primer (2016).

Berdasarkan hasil pengolahan data masing-masing variabel untuk kehidupansosial penambang emas Kelurahan Pasar Hilir dapat digambarkan bahwa : Pertama, kerabat adalah keluarga, sanak famili, teman sejawat atau teman kerja (Sutan Rajasa,2002: 298). Jadi dengan begitu dapat dikatakan bahwa sistem kekerabatan merupakan cara untuk mengatur atau cara dalam mengatur hubungan sesama keluarga, sanak famili, teman sejawat maupun teman kerja berdasarkan adanya aturan yang dibuat bersama secara turun temurun maupun berkala.

Untuk mengenal lebih jauh mengenai sistem kekerabatan tersebut sebelumnya kita harus terlebih dahulu memahami lahirnya sistem kekerabatan tersebut yakni rumah tangga dan keluarga inti. Koentjaraningrat (2005) misalnya menjelaskan bahwa rumah tangga yang merupakan keluarga inti adalah pemegang atau inti dari sistem kekerabatan.Lebih lanjut seperti yang dikatakan Koentjaraningrat bahwa pasangan suami istri membentuk suatu kesatuan sosial yang mengurus ekonomi rumah tangganya. Rumah tangga biasanya terdiri dari satu keluarga inti, tapi mungkin juga terdiri dari dua sampai tiga keluarga inti (Koentjaraningrat,2005: 103).

Pada variabel hubungan kekerabata penambang emas sudah dalam kategori baik, hal ini dapat dilihat pada banyaknya jawaban masyarakat 
penambang emas yang menyatakan bahwa rata-rata hubungan dengan keluarga, tetangga dan warga atau masyarakat masih dalam kondisi baik .

Kedua, pada variabel cara pandang terhadap pergaulan yang dilihat dari 2 indikator yaitu : 1). Egoisme, 2). solidaritas berkategori cukup baik. Pergaulan merupakan jalinan hubungan sosial antara seseorang dengan orang lain yang berlangsung dalam jangka relatif lama sehingga terjadi saling mempengaruhi satu dengan lainnya. Sikap sosial dapat dilihat dari adanya kerjasama, sikap tenggang rasa, dan solidaritas. (Soetjipto dan Sjafioedin,1994 : 44).

a. Aspek Kerjasama

Kerjasama merupakan suatu hubungan saling bantu membantu dari orang-orang atau kelompok orang dalam mencapai suatu tujuan. Dalam buku Psikologi Sosial dijelaskan bahwa: “ Kerjasama adalah kecenderungan untuk bertindak dalam kegiatan kerja bersamasama menuju suatu tujuan" (Ahmadi, 2000 : 89). Dengan demikian sikap kerjasama adalah merupakan suatu kecenderungan untuk bertindak dalam kegiatan kerjasama untuk mencapai suatu tujuan tertentu. Selanjutnya dalam buku Pedoman Umum Budi Pekerti dijelaskan bahwa: "Ciri-ciri orang yang mampu bekerjasama dengan orang lain adalah berperan dalam berbagi kegiatan gotong royong tidak membiarkan teman atau keluarga mengalami suatu masalah secara sendiri dan bersikap mengutamakan hidup bersama berdiri sama tinggi dan duduk sama rendah" (Depdikbud, 2001 : 28). b. Aspek Solidaritas

Solidaritas mempunyai arti adanya kecenderungan seseorang dalam melihat ataupun memperhatikan keadaan orang lain. Menurut Gerungan dalam bukunya Psikologi Sosial dijelaskan bahwa: "Solidaritas dapat diartikan sebagi kecenderungan dalam bertindak terhadap seseorang yang mengalami suatu masalah yakni berupa memperhatikan keadaan orang tersebut" (Gerungan, 1996 : 52). Dengan demikian solidaritas merupakan salah satu bentuk sikap sosial yang dapat dilakukan seseorang dalam melihat ataupun memperhatikan orang lainterutama seseorang yang mengalami suatu masalah.

c. Aspek Tenggang Rasa

Dalam buku Psikologi Sosial dijelaskan bahwa: "Tenggang rasa adalah seseorang yang selalu menjaga perasaan orang lain dalam aktivitasnya sehari-hari” (Ahmadi, 2000 : 34). Selanjutnya dalam buku Pedoman Pedoman Umum Budi Pekerti dijelaskan bahwa: "Sikap tenggang rasa dapat dilihat dari adanya saling menghargai satu sama lain, menghindari sikap masa bodoh, tidak menggangu orang lain, selalu menjaga perasaan orang lain, dalam bertutur kata tidak menyinggung perasaan orang lain, selalu menjaga perasaan orang lain dalam pergaulan dan sebagainya" (Depdikbud, 2001 : 29). Dengan demikian dari pendapat ahli jelaslah bahwa tenggang rasa adalah perwujudan sikap dan prilaku seseorang dalam menjaga, menghargai dan menghormati orang lain.

1) Sikap negatif

Bentuk-bentuk sikap sosial seseorang yang negatif antara lain :

(a) Egoisme yaitu suatu bentuk sikap dimana seseorang merasa dirinya adalah yang paling unggul atas 
segalanya dan tidak ada orang atau benda apapun yang mampu menjadi pesaingnya.

b) Prasangka sosial adalah suatu sikap negatif yang diperlihatkan oleh individu atau kelompok terhadap individu lain atau kelompok lain.

c) Rasisme, yaitu suatu sikap yang didasarkan pada kepercayaan bahwa suatu ciri yang dapat diamati dan dianggap diwarisi seperti warna kulit merupakan suatu tanda perihal inferioritas yang membenarkan perlakuan diskriminasi terhadap orang-orang yang mempunyai ciriciri tersebut.

d) Rasialisme, yaitu suatu penerapan sikap diskriminasi terhadap kelompok ras lain. Misalnya diskriminasi ras yang pernah terjadi di Afrika Selatan.

e) Stereotip, yaitu citra kaku mengenai suatu ras atau budaya yang dianut tanpa memerhatikan kebenaran citra tersebut. Misalnya stereotip masyarakat Jawa adalah lemah lembut dan lamban dalam melakukan sesuatu.Stereotip tersebut tidak selalu benar, karena tidak semua orang Jawa memiliki sifat tersebut. (Ahmadi, 2007 : 94).

Berdasarkan hasil penelitian yang telah dilakukan, peneliti menemukan bahwa masih banyak masyarakat penambang emas yang masih memiliki sikap egoisme dan kurang solidaritas antar masyarakat. Hal ini bisa dilihat dari jawaban responden yang rata-rata menjawab cukup baik pada tiap-tiap pernyataan untuk variabel cara pandang terhadap pergaulan. jadi variabel cara pandang terhadap pergaulan berkategori cukup baik.

Ketiga, pada variabel gotong royong dalam masyarakat yang dilihat dari 3 indikator yaitu : 1) tenaga, 2) uang, 3) fikiran atau ide, kategorinya cukup baik. Gotong royong merupakan sikap positive yang mendukung dalam perkembangan suatu daerah dan juga perlu dipertahankan sebagai perwujudan kebiasaan melakukan suatu pekerjaan secara bersama-sama. (Kusnaedi, 2006).

Keith dalam Sulastri (1996:48) mengatakan bahwa gotong royong adalah keterlibatan mental pikiran, emosional dan perasaan seseorang dalam situasi kelompok yang mendorongnya untuk memberikan sumbangan dalam kelompok dalam usaha mencapai tujuan serta turut bertanggung jawab terhadap usaha yang telah dilakukan.

Berdasarkan pendapat beberapa ahli di atas maka gotong royong masyarakat dapat di kelompokkan dalam dua bagian, yaitu gotong royong dalam bentuk fisik dan gotong royong non fisik. Gotong royong dalam bentuk fisik antara lain :1) tenaga, 2) Barang atau material, sedangkan gotong royong non fisik seperti : 1) pikiran, 2)gagasan, 3) ide yang dapat membantu dalam menjaga kebersihan lingkungan tempat tinggal.

Berdasarkan hasil penelitian dilihat dari variabel cara pandang masyarakat terhadap gotong royong ditemukan bahwa budaya gotong royong yang telah terjadi dalam masyarakat saat ini mendapat kategori cukup baik.hal ini dikarenakan masih banyaknya masyarakat yang kurang peduli akan gotong royong dan lebih memilih memberikan upah kepada orang lain untuk kegiatan-kegiatan yang ada dalam masyrakat.

Keempat, pada variabel kehidupan rumah tangga penambang emas yang dilihat dari 3 indikator yaitu :1) 
perkawinan, 2) perceraian, 3) keharmonisan, kategorinya adalah baik. Rumah tangga adalah sekelompok orang yang mendiami sebagian atau seluruh bangunan fisik dan biasanya tinggal serta makan satu dapur. Makan dari satu dapur berarti pembiayaan keperluan apabila pengurusan kebutuhan seharihari dikelola bersama-sama. Anggota rumah tangga adalah semua orang yang bertempat tinggal disuatu rumah, baik yang berada di rumah pada waktu pencacahan maupun yang sementara tidak ada. (Mantra, 2003). Anggota rumah tangga yang bepergian 6 bulan atau lebih dan anggota rumah tangga yang bepergian kurang dari 6 bulan tetapi dengan tujuan pindah dan tamu yang tinggal di rumah tangga kurang dari 6 bulan tetapi akan bertempat tinggal lebih dari 6 bulan akan dianggap sebagai anggota rumah tangga.Akan tetapi masih ada beberapa dari para penambang yang pernah bercerai.

Berdasarkan hasil penelitian dilihat dari variabel kehidupan rumah tangga penambang emas ditemukan bahwa untuk kehidupan rumah tangga penambang emas dikategorikan pada kategori baik Hal ini dapat dilihat oleh peneliti pada saat observasi dan wawancara yang mana kehidupan rumah tangga masyarakat dilihat dari indikator keharmonisan sangat harmonis, hanya ada 8 responden masyarakat penambang emas yang pernah bercerai. Sedangkan untuk indikator perkawinan, rata-rata masyarakat penambang emas tidak merupakan perkawinan silang atau perkawinan yang dilakukan berdasarkan garis keturunan.

\section{SIMPULAN}

Berdasarkan hasil penelitian dan pembahasan tentang kondisi sosial masyarakat penambang emas di Kelurahan Pasar Hilir Kecamatan Panyabungan Kabupaten Mandailing Natal sebanyak 56 orang maka dapat diambil kesimpulan bahwa berdasarkan hasil akumulasi tanggapan penambang emas terhadap keempat variabel dapat disimpulkan bahwa :Hubungan kekerabatan dengan masyarakat dalam kategori baik dengan skor 210,54, . Cara pandang penambang emas terhadap pergaulan masyarakat termasuk dalam kategori cukup baik dengan skor 184,28 ,. Cara pandang penambang emas terhadap gotong royong dalam masyarakat termasuk dalam kategori cukup baik dengan skor 189,37. Kehidupan rumah tangga penambang emas termasuk dalam kategori baik dengan skor 202 


\section{DAFTAR PUSTAKA}

Ahmadi, Abu, 2000. Psikologi Sosial. Jakarta: Rineka Cipta. 2007.Psikologi Sosial. Jakarta: Rineka Cipta.

Arikunto, Suharsini 2006.Prosedur Penelitian. Yogyakarta: Rineka Cipta.

Bungin, Burhan. 2011. Metodologi Penelitian Kuantitatif: Komunikasi, Ekonomi, dan Kebijakan Publik Serta Ilmu-ilmu Sosial Lainnya. Jakarta : Kencana

Nugroho.2015. Pemasaran Wisata Menara Gentala Arasy Di Kota Jambi.Skrispsi tidak diterbitkan.Padang: UNP.

Depdikbud, 2001.Pedoman Pembinaan Program Bimbingan di Sekolah. jakarta: Balai Pustaka.

Koentjarningrat, 2005.Pengantar Ilmu Antropologi. Jakarta: Rineka Cipta

Mangunwijaya, Forum. 2008. Kurikulum yang Mencerdaskan. Jakarta: Penerbit Buku Kompas.

Moleong, Lexy J. 2002. Metodologi Penelitian Kuantitatif. Bandung: Remaja Rosdakarya

Nawawi , 2000. Interaksi Sosisal.Jakarta : Gunung Agung. 2005.Metode Penelitian Bidang Sosial.Yogyakarta : Gajah Mada University Press.

Pusat Bahasa (1994). Kamus Besar Bahasa Indonesia Kontemporer. Depdiknas.RI

Servia, Ade. 2011. Kondisi Sosial Ekonomi Petani Kelapa Sawit Non-Kolektif di Kenagarian Kinali Kabupaten Pasaman Barat. Skrispsi tidak diterbitkan.Padang : UNP.

Sudjana, Nana dan Ibrahim. 2007. Penelitian dan Penilaian Pendidikan. Bandung: Sinar Baru Algesindo.

Sugiyono. 2008. Metode Penelitian Kuantitatif, Kualitatif, dan $R \&$ D. Bandung :Alfabeta

Soekanto, 2012.Sosiologi Suatu Pengantar. Jakarta: Rajawali Pers.

Sumardi, Mulyanto dan Hand Dieter Ever. 1985. Kemiskinan dan Kebutuhan Pokok. Jakarta: CV. Rajawali

Soetcipto dan Sjaefioedin, 1994.Metodologi Ilmu Sosial. Jakarta. 